\title{
The effect of saturation of the soil absorbing complex with cations on the yield and chemical composition of grasses
}

\author{
STANISEAW MERCIK, WOJCIECH STEPIEN, TERESA MERCIK \\ Department of Agricultural Chemistry, Warsaw Agricultural University, \\ Rakowiecka 26/30, 02-528 Warsaw, Poland
}

(Received: March 27, 1986)

\begin{abstract}
Three year long pot experiments using medium sand were conducted with a Italian ryegrass, Lolium multiflorum. Two year pot experiments were also done on medium soil with meadow fescue, Festuca pratensis. Before the experiment was begun, the absorbing complexes of these soils were saturated with cations to very different degrees. The results of these experiments showed that the degree of saturation of the absorbing complexes with potassium and magnesium should increase as the size of the complex decreases. Increasing doses of potassium significantly widened the $\mathrm{K}:(\mathrm{Ca}+\mathrm{Mg}$ ) ratio in grasses and lowered their quality, while $\mathrm{Ca}$ and $\mathrm{Mg}$ slightly narrowed this ratio. However, it was not wider than the acceptable ratio, even with the highest $\mathrm{K}$ doses.
\end{abstract}

\section{INTRODUCTION}

In order to obtain high yields of good quality fodder, the proper proportions of cations in the absorbing complex are necessary. Some authors (Grunes, 1973; K a c K a c a s and R ó ż c ka, 1964; L itwiński, 1985; Nikolova, 1984) hold that for many plants, the $\mathrm{Ca}: \mathrm{Mg}$ : $: \mathrm{K}: \mathrm{H}$. ratio in the absorbing complex should be close to $65: 10: 5: 20$. Disturbing this ratio can not only lead to a lowering of the yield, but most importantly, to the worsening of the quality of the plants meant to be used as feed. It is exceptionally easy, under Polish soil conditions, to bring about extensive changes in the saturation of the absorbing complex with cations by improper fertilization. This is due to the large areas of light soils, poor in organic matter, acid and low in potassium and magnesium. For this reason, the effect of a wide degree of saturation of the absorbing complex with cations on the yields and chemical compositions of two species of grasses was studied. 


\section{METHODS}

A pot experiment was carried out in 1981-1983 using a Italian ryegrass, on a soil poor in organic matter $(1.3 \%)$, with the mechanical composition of medium sand, very acid $(\mathrm{pH} 4.4)$ and very poor in exchangeable forms of calcium (1.0 m.e. Ca), magnesium $(0.16 \mathrm{m.e} \mathrm{Mg})$ and potassium $(0.08$ m.e. $\mathrm{K}$ per $100 \mathrm{~g}$ soil). In the autumn of 1980 , various doses of calcium, magnesium and potassium were added to this soil, after which it was incubated until the spring of 1981. Before Italian ryegrass was sown, soil samples were taken and analysed for: $\mathrm{pH}$ in $\mathrm{KCl}$, hydrolytic acidity $(\mathrm{hH})$ and exchangeable forms of $\mathrm{Ca}, \mathrm{Mg}$ and $\mathrm{K}$ (Table 1). After two years of vegetation, the soil in most of the combinations was depleted of potassium, and therefore in the spring of 1983, this element was applied at a rate of one-half of the initial dose given in 1980 .

For the subsequent two years (1984-1985), pot experiments were done with meadow fescue, Festuca pratensis, on light soil $(26 \%$ silt and clay) containing $2.15 \%$ organic matter. During previous years, this soil had been brought by pot experiments to a very diverse state of saturation by cations of the absorbing complex. However, it was relatively poor in potassium and therefore, before the plants were sown in 1984-1985, 0.6 $\left(\mathrm{K}_{1}\right)$ or $1.5\left(\mathrm{~K}_{2}\right) \mathrm{g} \mathrm{K}_{2} \mathrm{O}$ per pot were applied. In the spring of $1984,0.2 \mathrm{~g}$ $\mathrm{MgO}$ per pot were also given in the combinations marked in Table 3 as $\mathrm{Mg}$.

Both experiments were conducted in Wagner pots containing $8.5 \mathrm{~kg}$ of soil. The basic, pre-planting fertilization was the same in all of the pots, and consisted of $0.8 \mathrm{~g}$ of $\mathrm{P}_{2} \mathrm{O}_{5}$ in the form of $\mathrm{Ca}\left(\mathrm{H}_{2} \mathrm{PO}_{4}\right)_{2}$ and $0.5 \mathrm{~g}$ $\mathrm{N}$ as $\mathrm{NH}_{4} \mathrm{NO}_{3}$ per pot per year in both experiments. Independently of this, $0.5 \mathrm{~g} \mathrm{~N}$ was applied over each new growth of Italian ryegrass and meadow fescue. Each year, 5 growths of Italian ryegrass and 4 of meadow fescue were collected.

The total contents of $\mathrm{K}, \mathrm{Ca}, \mathrm{Mg}, \mathrm{Na}, \mathrm{N}$ and $\mathrm{P}$ were determined in the samples of plants from each regrowth. Soil samples for analysis were taken each year before planting and after harvest in the last year of the study. The $\mathrm{pH}$ in $\mathrm{KCl}$, hydrolytic acidity $(\mathrm{hH})$ according to Kapen, and exchangeable forms of $\mathrm{Ca}, \mathrm{Mg}$ and $\mathrm{K}$ in $1 \mathrm{~N}$ ammonium acetate, pH 7, were determined in the soil. The cation content in water was calculated from the amount of cations determined as given above.

\section{RESULTS}

\section{Experiments with Italian ryegrass}

Increasing doses of $\mathrm{Ca}, \mathrm{Mg}$ and $\mathrm{K}$ had already systematically increased the amount of exchangeable forms of these components in the few month 
Table 1

The results of soil analysis before sowing Italiza ryegrass in the sying of 1931 and average values over $1981-1983$ after harvest

\begin{tabular}{|c|c|c|c|c|c|c|c|c|c|c|c|c|c|c|}
\hline \multirow{3}{*}{$\begin{array}{c}\text { Combi- } \\
\text { nation } \\
\text { No. }\end{array}$} & \multicolumn{11}{|c|}{ Spring of 1981} & \multirow{2}{*}{\multicolumn{3}{|c|}{$\begin{array}{l}\text { m.e. after harvest } \\
\text { of Italian ryegrass }\end{array}$}} \\
\hline & \multicolumn{6}{|c|}{ m.e. per $100 \mathrm{~g}$ soil } & \multicolumn{5}{|c|}{$\%$ in absorbing complex } & & & \\
\hline & $\mathrm{Ca}$ & $\mathrm{Mg}$ & $\mathrm{K}$ & $\mathbf{S}$ & $\mathrm{hH}$ & $\mathrm{T}$ & $\mathrm{Ca}$ & $\mathrm{Mg}$ & $\mathrm{K}$ & $\mathrm{V}$ & $\mathrm{pH}$ & $\mathrm{Ca}$ & $\mathrm{Mg}$ & $\mathrm{K}$ \\
\hline 1 & 1.06 & 0.16 & 0.03 & 1.30 & 2.79 & 4.09 & 26 & 4 & 2 & 32 & 4.4 & 1.24 & 0.16 & 0.07 \\
\hline 2 & 1.50 & 0.27 & 0.14 & 1.91 & 2.37 & 4.28 & 35 & 6 & 3 & 44 & 4.6 & 1.83 & 0.28 & 0.7 \\
\hline 3 & 1.64 & 0.37 & 0.18 & 2.19 & 2.15 & 4.34 & 38 & 9 & 4 & 51 & 4.9 & 2.03 & 0.28 & 0.07 \\
\hline 4 & 1.75 & 0.32 & 0.22 & 2.29 & 1.87 & 4.16 & 42 & 8 & 5 & 55 & 5.2 & 2.23 & 0.35 & 0.07 \\
\hline 5 & 2.14 & 0.42 & 0.29 & 2.85 & 1.33 & 4.23 & 51 & 10 & 7 & 68 & 5.7 & 2.40 & 0.35 & 0.08 \\
\hline 6 & 3.18 & 0.68 & 0.43 & 4.29 & 1.02 & 5.31 & 60 & 13 & 9 & 82 & 6.4 & 3.22 & 0.48 & 0.11 \\
\hline 7 & 3.57 & 0.77 & 0.49 & 4.83 & 0.81 & 5.64 & 63 & 14 & 9 & 86 & 6.4 & 3.76 & 0.56 & 0.17 \\
\hline 8 & 2.18 & 0.16 & 0.26 & 2.60 & 1.38 & 3.98 & 55 & 4 & 7 & 65 & 6.0 & 2.50 & 0.14 & 0.08 \\
\hline 9 & 1.84 & 0.54 & 0.28 & 2.65 & 1.36 & 4.02 & 46 & 13 & 7 & 66 & 5.9 & 2.12 & 0.45 & 0.08 \\
\hline 10 & 1.64 & 0.93 & 0.30 & 2.87 & 1.36 & 4.23 & 38 & 22 & 7 & 68 & 5.9 & 1.68 & 0.76 & 0.07 \\
\hline 11 & 1.47 & 1.17 & 0.28 & 2.95 & 1.53 & 4.48 & 33 & 26 & 6 & 66 & 5.9 & 1.49 & 1.09 & 0.09 \\
\hline 12 & 1.14 & 1.47 & 0.28 & 2.89 & 1.50 & 4.39 & 26 & 33 & 6 & 66 & 5.8 & 1.26 & 1.36 & 0.08 \\
\hline 13 & 2.21 & 0.22 & 0.47 & 2.90 & 1.36 & 3.96 & 56 & 6 & 12 & 73 & 6.0 & 2.50 & 0.14 & 0.15 \\
\hline 14 & 1.86 & 0.54 & 0.42 & 2.92 & 1.36 & 4.30 & 43 & 13 & 10 & 68 & 6.0 & 2.05 & 0.40 & 0.16 \\
\hline 15 & 1.64 & 0.92 & 0.50 & 3.05 & 1.28 & 4.34 & 38 & 21 & 12 & 71 & 6.1 & 1.88 & 0.80 & 0.16 \\
\hline 16 & 1.43 & 1.30 & 0.47 & 3.20 & 1.36 & 4.56 & 31 & 29 & 10 & 70 & 6.0 & 1.52 & 1.12 & 0.14 \\
\hline 17 & 1.14 & 1.57 & 0.47 & 3.18 & 1.36 & 4.54 & 25 & 35 & 10 & 70 & 5.9 & 1.24 & 1.41 & 0.15 \\
\hline
\end{tabular}


long incubation period, while the total of these cations ( $T$ ) had risen from 1.3 to 4.8 m.e. per $100 \mathrm{~g}$ of soil. This increased the degree of basic saturation (V) from 32 to $86 \%$, lowered the hydrolytic acidity (hH) from 2.8 to 0.8 m.e. per $100 \mathrm{~g}$ of soil and increased the $\mathrm{pH}$ from 4.4 to 6.4 . In the second and third combination groups (c. 8-17), the saturation of the absorbing complex with calcium systematically dropped while the saturation with magnesium rose. However, the increase in exchangeable $\mathrm{Ca}$ or $\mathrm{Mg}$ as the result of fertilization was smaller (by $10-30 \%$ ) than could be expected from the doses applied. Also, there was significantly more exchangeable potassium on the higher $\mathbb{K}$ dose $(0.42-0.50$ m.e.) than on the lower dose (0.26-0.30 m.e. $\mathrm{K}$ per $100 \mathrm{~g}$ soil). The sum of the applied $\mathrm{Ca}+\mathrm{Mg}$ doses was, however, identical in all of the pots in the second and third combination groups (8-17). In spite of this, the total of exchangeable bases (S) and exchange capacity $(\mathrm{T})$ rose slightly as the $\mathrm{Mg}$ dose increased. It follows from this that magnesium entered the absorbing complex more rapidly than calcium. After harvest of Italian ryegrass, large differences in the amounts of exchangeable $\mathrm{Ca}$ and $\mathrm{Mg}$ in the particular combinations and similar amounts of potassium were found. Comparison of the results of soil samples run before sowing and after harvest of Italian ryegrass indicates that the amount of exchangeable $\mathrm{Ca}$ even rose slightly, the amount of exchangeable $\mathrm{Mg}$ fell and that the amount of exchangeable $K$ decreased by a large amount, in spite of the fact that this element was applied in the spring of 1983 .

As the degree of basic saturation (V) of the absorbing complex increased (c. 1-7), Italian ryegrass yields rose significantly (Table 2) until the degree of basic saturation attained $80 \%$. At this level, the soil $\mathrm{pH}$ was 5.6 and the $\mathrm{Ca}: \mathrm{Mg}: \mathrm{K}: \mathrm{H}$ ratio equalled $60: 13: 9: 18$. Further increases of $\mathrm{Ca}+\mathrm{Mg}+\mathrm{K}$ doses had no effect on the yield.

Simultaneous lowering of the saturation of the absorbing complex with calcium and increasing it with magnesium also increased the Italian ryegrass yields, this occurring at both levels of potassium fertilization. The highest Italian ryegrass yields were obtained at $33-38 \%$ saturation of the absorbing complex with calcium, 21-27\% magnesium and $8-9 \%$ potassium. A clear decrease in yield was obtained when the $\mathrm{Mg}$ content in the absorbing complex was below $13 \%$ and $\mathrm{Ca}$ below $30 \%$. From among the studied cations, the greatest influence on yield was shown by potassium. Significantly lower yields were obtained when the $\mathrm{K}$ level in the absorbing complex was at $6-7 \%$ than when it equalled $10-12 \% \mathrm{~K}$ in $\mathrm{T}$. These results indicate that the yields were much more dependent on the saturation of the absorbing complex with potassium and magnesium than with calcium.

The content of all of the studied nutrients in the Italian ryegrass was different in the particular studied objects. Especially large differ- 
Table 2

Yields ( $\mathrm{g}$ dry weight per pot) and chemical composition Italian ryegrass ( $\%$ dry weight) as a function of the degree of basic saturation of the soils. Averages over 3 years

\begin{tabular}{|c|c|c|c|c|c|c|c|c|c|c|c|c|c|}
\hline \multirow{3}{*}{$\begin{array}{l}\text { Combination } \\
\text { No. (tab. 1) }\end{array}$} & \multicolumn{3}{|c|}{ Yield } & \multicolumn{4}{|c|}{ Regrowth 1,\% } & \multicolumn{4}{|c|}{ Regrowth 4, \% } & \multirow{2}{*}{\multicolumn{2}{|c|}{$\begin{array}{l}\text { Total cation uptaken } \\
\text { in m.e. per } 100 \mathrm{~g} \\
\text { d.m. regrowth }\end{array}$}} \\
\hline & \multirow{2}{*}{ total } & \multicolumn{2}{|c|}{ regrowth } & \multirow{2}{*}{ K } & \multirow{2}{*}{$\mathbf{M g}$} & \multirow{2}{*}{$\mathrm{Ca}$} & \multirow{2}{*}{$\frac{\mathrm{K}}{\mathrm{Ca}+\mathrm{Mg}}$} & \multirow{2}{*}{$\mathrm{K}$} & \multirow{2}{*}{$\mathrm{Mg}$} & \multirow{2}{*}{$\mathrm{Ca}$} & \multirow{2}{*}{$\frac{\mathrm{K}}{\mathrm{Ca}+\mathrm{Mg}}$} & & \\
\hline & & 1 & 4 & & & & & & & & & 1 & 4 \\
\hline 1 & 2.3 & 1.8 & 0.1 & 1.43 & 0.33 & 0.61 & 0.7 & - & - & - & - & 96 & - \\
\hline 2 & 7.5 & 3.1 & 0.7 & 2.03 & 0.23 & 1.18 & 0.7 & 0.73 & 0.23 & 1.26 & 0.2 & 130 & 101 \\
\hline 3 & 11.9 & 3.8 & 1.7 & 2.41 & 0.26 & 1.39 & 0.7 & 0.70 & 0.31 & 1.24 & 0.2 & 153 & 106 \\
\hline 4 & 20.5 & 5.9 & 4.3 & 2.46 & 0.29 & 1.47 & 0.7 & 1.18 & 0.36 & 2.40 & 0.2 & 165 & 180 \\
\hline 5 & 26.1 & 6.6 & 6.8 & 2.68 & 0.28 & 1.34 & 0.8 & 1.14 & 0.38 & 2.62 & 0.2 & 159 & 192 \\
\hline 6 & 35.9 & 8.6 & 9.8 & 3.18 & 0.35 & 1.27 & 0.9 & 1.27 & 0.40 & 1.94 & 0.3 & 174 & 163 \\
\hline 7 & 36.7 & 8.8 & 9.3 & 3.57 & 0.35 & 1.09 & 1.1 & 1.41 & 0.47 & 1.72 & 0.3 & 175 & 161 \\
\hline 8 & 22.5 & 5.9 & 4.4 & 2.76 & 0.15 & 1.63 & 0.7 & 1.37 & 0.18 & 2.75 & 0.2 & 165 & 188 \\
\hline 9 & 27.2 & 5.9 & 6.8 & 2.80 & 0.30 & 1.40 & 0.8 & 1.14 & 0.36 & 2.22 & 0.2 & 167 & 170 \\
\hline 10 & 28.0 & 7.0 & 7.2 & 2.64 & 0.43 & 1.08 & 0.8 & 0.97 & 0.61 & 1.93 & 0.2 & 162 & 172 \\
\hline 11 & 29.2 & 7.3 & 7.8 & 2.75 & 0.51 & 0.81 & 0.9 & 0.75 & 0.72 & 1.49 & 0.2 & 155 & 154 \\
\hline 12 & 29.9 & 7.8 & 7.5 & 2.75 & 0.63 & 0.59 & 0.9 & 0.73 & 0.90 & 1.09 & 0.2 & 153 & 148 \\
\hline 13 & 35.9 & 7.5 & 9.3 & 3.76 & 0.16 & 1.19 & 1.4 & 1.35 & 0.11 & 2.12 & 0.3 & 169 & 150 \\
\hline 14 & 35.8 & 8.7 & 10.5 & 3.55 & 0.31 & 0.98 & 1.3 & 1.18 & 0.34 & 1.72 & 0.3 & 166 & 145 \\
\hline 15 & 40.3 & 9.3 & 10.7 & 3.26 & 0.38 & 0.73 & 1.2 & 1.03 & 0.49 & 1.39 & 0.3 & 151 & 137 \\
\hline 16 & 40.5 & 8.7 & 10.9 & 3.41 & 0.44 & 0.56 & 1.4 & 1.08 & 0.59 & 1.12 & 0.3 & 152 & 133 \\
\hline 17 & 27.9 & 7.8 & 10.7 & 3.47 & 0.55 & 0.46 & 1.3 & 0.98 & 0.73 & 0.86 & 0.2 & 158 & 129 \\
\hline LSD & 2.7 & & & & & & & & & & & & \\
\hline
\end{tabular}


ences were found in the first regrowth. The percentage of $\mathrm{K}$, and a lesser degree of $\mathrm{Mg}$, increased as the $\mathrm{Ca}+\mathrm{Mg}+\mathrm{K}$ doses increased. The sum of the basic cations, $\mathrm{Ca}+\mathrm{Mg}+\mathrm{K}$, also increased, then fell after medium doses were exceeded. It results from this that the accompanying cations did not hinder the uptake of potassium and that higher doses of this element acted more antagonistically on calcium than on magnesium uptake. The narrowing of the $\mathrm{Ca}: \mathrm{Mg}$ ratio in the absorbing complex clearly lowered the Ca percentage in the dry weight. This, however, had no influence on the $K$ percentage in the first regrowth. In the last one, when the soil was low in potassium, the $\mathrm{K}$ content of the plant decreased with increasing $\mathrm{Mg}$ doses. This shows that with a low potassium content in the soil, magnesium can act antagonistically towards potassium uptake, while calcium does not.

The ratio of the $\mathrm{K}:(\mathrm{Ca}+\mathrm{Mg})$ equivalents in the first I. ryegrass regrowth widened both as the dosages of $\mathrm{Ca}+\mathrm{Mg}+\mathrm{K}$ increased and with higher $\mathrm{K}$ doses. However, even with the highest $\mathrm{K}$ doses, this ratio was not wider in any of the regrowths than that accepted as critical in plants intended for feed. This results mainly not from the lower $\mathrm{K}$ content, but rather from the high $\mathrm{Ca}$ content in Italian ryegrass. The differences in the $\mathrm{Ca}: \mathrm{Mg}$ ratio in the absorbing complex did not influence the $\mathrm{K}:(\mathrm{Ca}+\mathrm{Mg})$ ratio in the plant.

\section{Experiments with meadow fescue, Festuca pratensis}

The soil on which pot experiments were done with meadow fescue differed greatly in respect to acidity and magnesium and potassium supply, and to a lesser extent, in the amount of exchangeable calcium and degree of basic saturation (Table 3). The objects fertilized with magnesium had much more exchangeable $\mathrm{Mg}(2.2-2.3 \mathrm{~m} . e$.) than those not given this element $(0.6-0.7)$ m.e. $\mathrm{Mg}$ per $100 \mathrm{~g}$ soil. The soils fertilized with higher doses of potassium contained more than twice as much exchangeable $\mathrm{K}(0.46$ m.e.) than those given lower doses $(0.2$ m.e. $\mathrm{K}$ per $100 \mathrm{~g})$. The magnesium content, especially magnesium with calcium, clearly increased the total of exchangeable basic cations (from 7.4 to 11.2 m.e.) and the degree of basic saturation of the soil (from 70 to $94 \%$ ). The hydrolytic acidity, on the other hand, fell from 3.2 to 0.8 m.e. per $100 \mathrm{~g}$.

All of the studied nutrients ( $\mathrm{Ca}, \mathrm{Mg}$ and $\mathrm{K}$ ) significantly increased the meadow fescue yields (Table 4). However, potassium had the greatest influence. The highest yields were obtained with higher saturation of the absorbing complex with potassium $(4 \%)$, but along with the use of calcium or magnesium. Saturation of the absorbing complex with calcium and magnesium had a smaller effect on the yields, since the highest 
Table 3

The physico-chemical properties of soil tefcre the start of the fet exferiment in 1984 and aftcr harvest in 1985

\begin{tabular}{|c|c|c|c|c|c|c|c|c|c|c|c|c|c|}
\hline \multirow{3}{*}{ Fertilization } & \multicolumn{6}{|c|}{1984} & & & & & \multirow{3}{*}{$\mathrm{pH}$} & \multirow{2}{*}{\multicolumn{2}{|c|}{$\begin{array}{l}\text { m.e. after harvest } \\
\text { of meadow fescue }\end{array}$}} \\
\hline & \multicolumn{6}{|c|}{ m.e. per $100 \mathrm{~g}$ of soil } & \multicolumn{4}{|c|}{$\%$ inabsorbing complex } & & & \\
\hline & $\mathrm{Ca}$ & $\mathrm{Mg}$ & $\mathbf{K}$ & $\mathrm{S}$ & $\mathrm{hH}$ & $T$ & $\mathrm{Ca}$ & $\mathrm{Mg}$ & $\mathrm{K}$ & $\mathrm{V}$ & & $\mathrm{Mg}$ & $\mathbf{K}$ \\
\hline $\mathbf{K}_{1}$ & 6.60 & 0.62 & 0.21 & 7.43 & 3.20 & 10.63 & 62 & 6 & 2 & 70 & 4.0 & 0.17 & 0.16 \\
\hline $\mathrm{K}_{2}$ & 6.60 & 0.62 & 0.45 & 7.69 & 2.90 & 10.59 & 62 & 6 & 4 & 72 & 4.1 & 0.13 & 0.20 \\
\hline $\mathrm{K}_{\mathbf{1}} \mathrm{Mg}$ & 6.65 & 2.25 & 0.19 & 9.09 & 1.80 & 10.89 & 61 & 21 & 2 & 84 & 4.5 & 0.84 & 0.10 \\
\hline $\mathrm{K}_{2} \mathrm{Mg}$ & 6.65 & 2.29 & 0.46 & 9.40 & 1.60 & 11.00 & 60 & 21 & 4 & 85 & 4.8 & 0.70 & 0.10 \\
\hline $\mathrm{K}_{1} \mathrm{Ca}$ & 8.10 & 0.67 & 0.20 & 8.97 & 1.40 & 10.37 & 78 & 6 & 2 & 86 & 6.2 & 0.09 & 0.05 \\
\hline $\mathrm{K}_{2} \mathrm{Ca}$ & 8.45 & 0.67 & 0.46 & 9.58 & 1.20 & 10.78 & 78 & 6 & 4 & 88 & 6.5 & 0.07 & 0.06 \\
\hline $\mathrm{K}_{1} \mathrm{Mg} \mathrm{Ca}$ & 8.15 & 2.23 & 0.20 & 10.58 & 0.90 & 11.48 & 71 & 19 & 2 & 92 & 6.5 & 0.48 & 0.06 \\
\hline $\mathrm{K}_{2} \mathrm{Mg} \mathrm{Ca}$ & 8.45 & 2.28 & 0.45 & 11.18 & 0.80 & 11.98 & 71 & 19 & 4 & 94 & 6.7 & 0.42 & 0.08 \\
\hline
\end{tabular}




\section{Table 4}

Yield (g dry weight per pot) and chemical composition of meadow fescue ( $\%$ dry weight) as a function of the degree of basic saturation of the absorbing complex. Average over 2 years

\begin{tabular}{|c|c|c|c|c|c|c|c|c|c|c|c|c|c|}
\hline \multirow{4}{*}{ Fertilization } & \multicolumn{3}{|c|}{ Yield } & \multicolumn{4}{|c|}{ Regrowth $1, \%$} & \multicolumn{4}{|c|}{ Regrowth $4, \%$} & \multirow{3}{*}{\multicolumn{2}{|c|}{$\begin{array}{l}\text { Sum of cations } \\
\text { taken up, m.e. } \\
\text { per } 100 \mathrm{~g} \text { dry } \\
\text { weight, regrowth }\end{array}$}} \\
\hline & \multirow{3}{*}{ total } & \multicolumn{2}{|c|}{ regrowth } & \multirow{3}{*}{$\mathbf{K}$} & \multirow{3}{*}{$\mathrm{Mg}$} & \multicolumn{2}{|c|}{$\mathbf{K}$} & \multirow{3}{*}{$\mathbf{K}$} & \multirow{3}{*}{$\mathrm{Mg}$} & \multicolumn{2}{|c|}{ K } & & \\
\hline & & 1 & 4 & & & M & $\mathrm{Ca}$ & & & $\mathrm{Mg}$ & $\mathrm{Ca}$ & & \\
\hline & & & & & & & & & & & & 1 & 4 \\
\hline$K_{1}$ & 15.9 & 6.5 & 1.3 & 2.43 & 0.36 & 1.20 & 0.7 & 0.94 & 0.40 & 1.50 & 0.2 & 152 & 132 \\
\hline $\mathrm{K}_{2}$ & 18.8 & 7.6 & 2.1 & 2.85 & 0.34 & 0.98 & 0.9 & 1.23 & 0.31 & 1.22 & 0.4 & 150 & 119 \\
\hline $\mathrm{K}_{1} \mathrm{Mg}$ & 18.6 & 6.9 & 2.7 & 2.17 & 0.73 & 0.78 & 0.6 & 0.74 & 0.85 & 1.23 & 0.1 & 156 & 151 \\
\hline $\mathrm{K}_{2} \mathrm{Mg}$ & 22.2 & 7.5 & 6.5 & 3.67 & 0.51 & 0.71 & 1.2 & 1.39 & 0.72 & 0.99 & 0.3 & 171 & 145 \\
\hline $\mathrm{K}_{1} \mathrm{Ca}$ & 18.4 & 6.8 & 3.2 & 2.11 & 0.47 & 1.07 & 0.7 & 0.77 & 0.49 & 1.62 & 0.2 & 146 & 142 \\
\hline $\mathrm{K}_{2} \mathrm{Ca}$ & 22.4 & 6.8 & 5.6 & 3.48 & 0.40 & 0.89 & 1.2 & 0.04 & 0.47 & 1.49 & 0.2 & 166 & 151 \\
\hline $\mathrm{K}_{1} \mathrm{Mg} \mathrm{Ca}$ & 20.4 & 6.8 & 4.3 & 1.90 & 0.75 & 0.79 & 0.5 & 0.71 & 0.85 & 1.50 & 0.1 & 150 & 164 \\
\hline $\mathrm{K}_{\mathbf{2}} \mathrm{Mg} \mathrm{Ca}$ & 22.7 & 7.2 & 5.3 & 3.65 & 0.51 & 0.70 & 1.2 & 1.15 & 0.75 & 1.21 & 0.2 & 171 & 151 \\
\hline LSD & 1.9 & & & & & & & & & & & & \\
\hline
\end{tabular}


yields were obtained both at $6 \%$ and $21 \% \mathrm{Mg}$ in $\mathrm{T}$ and at 60 and $78 \%$ $\mathrm{Ca}$ in $\mathrm{T}$. However, this was on soil rich in magnesium and calcium. The effect of the studied nutrients persisted over the subsequent regrowths and was the greatest in the fourth.

The potassium content in the fescue was clearly lower in the subsequent regrowths as the result of the systematic depletion of the soil of this element. The calcium and magnesium contents in the subsequent regrowths remained on a similar level. Only in the first regrowth and on a higher potassium dose was a $\mathrm{K}$ content in the plant obtained which exceeded that regarded as acceptable in feed. Higher doses of potassium and magnesium significantly increased the content of these elements in the plants. The calcium content, however, clearly decreased with potassium or magnesium fertilization, while it was dependent on calcium fertilization.

The fescue contained relatively large amounts of calcium and magnesium, and for this reason, the $\mathrm{K}:(\mathrm{Ca}+\mathrm{Mg})$ ratio in the plant was very narrow. Even in the first regrowth and higher potassium dose, this ratio did not exceed 1.2:1. The $\mathrm{K}:(\mathrm{Ca}+\mathrm{Mg})$ ratio widened when a higher potassium dose was given, and only slightly narrowed when $\mathrm{Ca}$ and $\mathrm{Mg}$ were applied.

The study showed differences in the $\mathrm{K}, \mathrm{Mg}$ and $\mathrm{Ca}$ percentages in the plants, however, the sum of cations taken up, when calculated per $100 \mathrm{~g}$ dry weight, was similar in all of the studied combinations.

The studied factors did not differentiate the contents of $N, P$ and $\mathrm{Na}$ in Italian ryegrass or meadow fescue, and for this reason these results are not included in the tables.

\section{DISCUSSION}

For high yields of high quality feed to be obtained, it is necessary to have not only the proper amounts, but also the proper proportions of cations in the absorbing complex. Some authors report that the $\mathrm{Ca}: \mathrm{Mg}$ : $: \mathrm{K}: \mathrm{H}$ ratio in the absorbing complex should be close to $65: 10: 5: 20$ (Grunes, 1973; Ka c Kacas and Różycka, 1964; Litwiński, 1985; Nikolova, 1984). However, because of the different requirements of the different plant species for the cations listed above, one optimal ratio of these cations for all plants cannot be expected. In respect to grasses, it is most often given that the amount of potassium and, to a lesser extent, magnesium should exceed 5 and $10 \%$, respectively, in the absorbing complex ( $\mathrm{Gr}$ un es, 1973; Kam a ta, 1977; Litwinski, 1985; Mercik et al., 1984; Pletl et al., 1979). In our experiments, potassium also exerted a great influence on the yield. For example, the yields of Italian ryegrass were significantly higher at $10-11 \% \mathrm{~K}$ than 
at $6-7 \% \mathrm{~K}$ in the absorbing complex. The yields of fescue were also higher at $4 \% \mathrm{~K}$ than at $2 \% \mathrm{~K}$ in the absorbing complex. Such significant differences in the optimal saturation of the absorbing complex with potassium result from the fact that, under the conditions of our experiment, Italian ryegrass was cultivated on soil with a significantly lower exchange capacity. It results from this that the percentage of $\mathrm{K}$ in the absorbing complex should be greater the smaller the size of the absorbing complex of the soil.

Increasing the saturation of the absorbing complex with magnesium and decreasing that with calcium also increased the darnel yields, the highest being obtained at $21-27 \% \mathrm{Mg}$ in $\mathrm{T}$. Lowering or raising the magnesium saturation of the absorbing complex lowered the Italian ryegrass yields. High meadow fescue yields were obtained, on the other hand, both with very low $(6 \%)$ and high $(19-21 \%)$ saturation of the $a b-$ sorbing complex with magnesium. On the soil with a small exchange capacity (4-4.5 m.e.), the highest Italian ryegrass yields were obtained at $21-27 \% \mathrm{Mg}$ in $\mathrm{T}$, and $10-12 \% \mathrm{~K}$ in $\mathrm{T}$, while on the soil with a high exchange capacity (10.5-11 m.e.), high fescue yields were already obtained by $6 \% \mathrm{Mg}$ in $\mathrm{T}$ and $4 \% \mathrm{~K}$ in $\mathrm{T}$. It can be concluded from this that also in the case of magnesium, it is desirable to have a higher degree of saturation with this element, the smaller the absorbing complex of the soil. Other authors also report that on soils with a small exchange capacity, the absorbing complex should be saturated with protassium and magnesium (Litwiński, 1985; Nikolova, 1984; Scheffer and Schachtschabel, 1970).

High yields of Italian ryegrass were obtained with a significantly lower saturation with calcium than with that given above, that is, already starting from $30 \% \mathrm{Ca}$ in $\mathrm{T}$.

The quantity and proportions of cations in the absorbing complex usually exert a greater influence on the chemical composition of grasses than on their yields. In the case of plants meant for fodder for ruminants, it is important that the plants do not contain too much potassium, and that they do contain relatively high amounts of $\mathrm{Ca}, \mathrm{Mg}$ and $\mathrm{Na}$. It is accepted that fodder should not have more than $2.2-2.5 \% \mathrm{~K}$ in dry weight. More often, though, it is accepted that the ratio of equivalents $\mathrm{K}:(\mathrm{Ca}+\mathrm{Mg})$ cannot be wider than $2.2: 1$. When it is wider, the cattle fed on such fodder become afflicted with grass tetany ( $\mathrm{F}$ ing er and Werk, 1973; Grunes, 1973; M a yland and Grunes, 1974; Mika, 1983; Reynold and W a 11, 1982; R eid et al., 1978). As can be seen from our studies and those of other authors, the potassium content of a plant can increase significantly as the result of fertilization with this element, this occurring regardless of the amounts of $\mathrm{Ca}$ and $\mathrm{Mg}$ in the soil (Johanson and $\mathrm{Hahlin,} \mathrm{1977;} \mathrm{Litwinski,} \mathrm{1985;} \mathrm{Mazera}$ 
et al., 1978; Mengel and Wichens, 1979; Mercik et al., 1984; Mercik and Panak, 1984). The magnesium content can also be significantly increased in a plant by fertilization with this element, but only when the $\mathrm{Mg}$ uptake is not hindered by $\mathrm{K}$ ( $\mathrm{F}$ ing er and W erk, 1973; Kimura and Kurashima, 1983; Litwiński, 1985; Maze$\mathrm{r}$ a et al., 1978). The calcium content, however, is more often dependent on the potassium uptake than on the amount of $\mathrm{Ca}$ in the nutritional environment (II a ls te a d et al., 1958; $\mathrm{J}$ oh a n son and $\mathrm{H}$ a hl in, 1977; Litwinski, 1985). It results from this that in order to maintain the narrow $\mathrm{K}:(\mathrm{Ca}+\mathrm{Mg})$ ratio while applying the necessary high potassium doses needed for high yields, a high level of bivalent cations is necessary in the fodder. This can be attained by, among others, the cultivation of the appropriate grass species or papilionaceous plants containing large amounts of $\mathrm{Ca}$ and $\mathrm{Mg}$. In our pot experiments, both Italian ryegrass and meadow fescue contained much $\mathrm{Ca}$ and $\mathrm{Mg}$, and therefore, even with the highest doses, the $\mathrm{Ka}$ : $(\mathrm{Ca}+\mathrm{Mg})$ ratio was never wider than acceptable. This ratio often slightly narrowed when calcium and magnesium fertilization had been applied.

As shown in numerous studies, the content of magnesium in plants can be increased in many ways. For example, by fertilizing with this element (Christenson et al., 1973; Finger and Werk, 1973; Litwiński, 1985; Ma yl and and Grunes, 1974; Mercik et al., 1984; Reynold and Wall, 1982; Schockeg and Reid, 1984), by the cultivation of the appropriate grass species ( $\mathrm{H}$ a n s o n et al., 1983; Mika, 1983; P f l u ger and $\mathrm{N}$ emeth, 1972; R eid et al., 1978; R in n e et al., 1978; Schockeg and $\mathrm{Reid}, 1984$ ) and by lowering the soil moisture (Charles et al., 1978; Elkins et al., 1978; Mengel and Wichens, 1979; West and Reynolds, 1984). The magnesium content of the plant also rises when higher temperatures occur during vegetation (Grunes, 1973; R e ynold and Wall, 1982; R eid et al., 1978; West and Reynolds, 1984) and when lower nitrogen doses are used, especially when used in the form of nitrate ( $\mathrm{Gr}$ u es, 1973; $\mathrm{R}$ inn e et al., 1978).

\section{CONCLUSIONS}

1. As the exchange capacity of soils decreases, their absorbing complex should be saturated to a higher degree with potassium and magnesium. High yields on soil with an exchange capacity $=10$ m.e. were obtained when it contained over $6 \% \mathrm{Mg}$ and $4 \% \mathrm{~K}$, while on soil with an exchange capacity $=4 \mathrm{~m}$.e. per $100 \mathrm{~g}$, the highest yields were obtained at $21-27 \% \mathrm{Mg}$ and $10-11 \% \mathrm{~K}$ in the absorbing complex.

2. Even large differences in the saturation of the absorbing complex 
with calcium had no greater effect on the yield and chemical composition of the grasses.

3. As the doses of $\mathrm{K}$ increased, the $\mathrm{K}:(\mathrm{Ca}+\mathrm{Mg})$ ratio in the grasses widened significantly. Fertilization with calcium and magnesium only had a small effect on narrowing this ratio. However, due to the high $\mathrm{Ca}$ and $\mathrm{Mg}$ content in Italian ryegrass and meadow fescue, even the highest doses of $\mathrm{K}$ did not widen this ratio to the value accepted as critical.

4. The potassium content in the plant rose significantly as the doses of this element increased, irrespective of the level of fertilization with $\mathrm{Ca}$ and $\mathrm{Mg}$. The magnesium content also rose with increasing doses of $\mathrm{Mg}$, but only when it was not limited by high $\mathrm{K}$ doses. The calcium content was dependent more on the level of potassium fertilization than on fertilization with calcium.

\section{REFERENCES}

Charles B., et al, 1978. Grass tetany potential of tall fescue as affected by soil $\mathrm{O}_{2}$. Agron. Journ. 70: 309-311.

Christenson D. R., White R. P., Dol1 E. C., 1973. Yields and magnesium uptake by plants as affected by soil $\mathrm{pH}$ and calcium levels. Agron. Journ. 65: 205-206.

Elkins C. B., et al., 1978. Grass tetany of tall fescue as affected by soil $\mathrm{O}_{2}$. Agron. Journ. 70: 300-311.

Finger H., Werk O., 1973. Anhebung des Natriums and Magnesiumgehaltes der Weiderfuterpflanzen und Beeinflussung des Futterversehrs nach Dungung mit Magnesia - Kainit. Sonderh. Landw. Forsch 28/11: 190-196.

Grunes D. L., 1973. Grass tetany of cattle and sheep. Crop. Sci. Soc. of Amer., Wisconsin pp. 113-140.

$\mathrm{Hans}$ on R. G., et al., 1983. Yield quality and $\mathrm{K}:(\mathrm{Ca}+\mathrm{Mg})$ ratio of tall fescue breeding lines on amended and nonamended minesoil. Comun. Soil Sci. Plant Anal. 14: 263-275.

Halstead R. L., Maclean A. J., Nielsen K. F., 1958. Ca : Mg rations in soil and the yeild and compositions of alfalfa. Canad. Journ. Soil Sci. 38: 85-93.

Johanson O., Hahlin J., 1977. Potassium magnesium balance in soil for maximum yield. Proceedings of the intern. seminar on soil environment and fertility management in intensive agriculture. Tokyo - Japan pp. 487-495.

Ka c Ka cas M., Róży cka T., 1964. Niektóre bađania nad magnezem. Cz. 1. Roczn. Nauk. rol. 88: 586-603.

$\mathrm{Ka}$ a ta H., 1977. Ca - $\mathrm{Mg}-\mathrm{K}$ balance in volcanic ash soils to maxime vegetable production. Proceedings of the seminar on soil environment and fertility management in intensive agriculture. Tokyo - Japan pp. 496-501.

Kimura T., Kurashima K., 1983. Effect of $\mathrm{Ca}$ and $\mathrm{Mg}$ on soil and their composition of gras. Soil. Sci. Plant. Nutr. 29: 398.

Litwiński J., 1985. Wplyw wysycenia kompleksu sorpcyjnego gleb kationami na plonowanie i skład chemiczny kilku gatunków roślin. Praca doktorska wykonana w Katedrze Chemii Rolniczej SGGW - AR, Warszawa. 
Mazera M. M., Neugadoa O. V., I apsina L. V., 1978. Soderzhanie magnija $v$ travakh pri udobreni senokosov i pastbishk. Khim. v Selsk. Khoz. 16: $13-16$.

M a yland H. F., Grunes D. L., 1974. Magnesium concentration in Agropyron desortorum fertilized with $\mathrm{Mg}$ and N. Swed. I. Agric. Research 66: 79-82.

Menge $1 \mathrm{~K}$., W i chens E., 1979. Die Bedeutung der nichtaustauschbaren Kalium fraktion des Bodens für die Ertragsbildung von Weidergrass. Z. Pfl. Ernahr. Bodenk. 142: 836-847.

Mercik S., Goralski I., Goźliński H., Mercik T., 1984. Badania nad współdziałaniem potasu $\mathrm{z}$ magnezem $\mathrm{i}$ wapniem na różnych glebach $\mathrm{i}$ pod różnymi roślinami. Cz. III. Wpływ na plonowanie i skład chemiczny życicy w. i seradeli. Roczn. Glebozn. XXXV. 1: 81-96.

M e r cik S., Panak H., 1984. Vlijanie vzaimodejstvija kaltsija, magnija, kalija i natrija $v$ raznykh sootnosh enijakh na urozajj i khimicheskijj sostav rastenijj. Zesz. Probl. Post. Nauk roln. 285: 151-166.

M i ka V., 1983. The content of $\mathrm{Mg}$ and other minerals in spring fodder. Rosta Vyroba 29, 9: 927-935.

Nikolova M., 1984. Metody sozdanija optimalnogo urovnija kalija $v$ pochve i stepen nasyshhenija. Nauchnoj konferenija SEB. Praga 28.08.1984.

Pfluger R., Nemeth K., 1972. Die kationengehalte verschidener Weidelgrassorten in Abhangigkeit von Boden und Dungung. Sondern. Landw. Forsch. 27/II: $110-116$.

Pletl L., Mechnert C., Bauer I., 1979. The effect of potassium fertilization on potassium, magnesium and sodium content of fodder grown on marshy soil. Soil and Fertilizers 42: 403 .

Reynold J. H., Wall D. H., 1982. Concentration of $\mathrm{Mg}, \mathrm{Ca}, \mathrm{P}, \mathrm{K}$ and crude protein in fertized tall fescue. Agron. Journ. 74: 950-954.

Reid R. L., I ung G. A., Roemig I. I., Kocher R. E., 1978. Mineral utilization by lambs and guinea pigs fed $\mathrm{Mg}$ - fertilized grass and legume hays. Agron. Journ. 70: 9-14.

Rinne S. L., Sillanpaa M., Auckuna E., Hevola S. L., 1978. The effect of nitrogen fertilization on $\mathrm{K}:(\mathrm{Ca}+\mathrm{Mg})$ ratio in grass. Ann. Agric. Fenn. 17: 83-88.

Scheffer F., Schachtschabel P., 1970. Lerbuch der Bodenkunde. Z. Volling neubearbeit Aufl. Stuttgart.

Schockeg W. L., Reid R. L., 1984. Partition of $\mathrm{Mg}$ in forage as affected by fertilization species, grown stage and samples preparation. Agron. Journ. 76: $565-568$.

West J. W., R e y nolds J. H., 1984. Cation composition of tall fescue as affected by $\mathrm{K}$ and $\mathrm{Mg}$ fertilization. Agron. Journ. 76: 676-680.

\section{WPEYW WYSYCENIA KOMPLEKSU SORPCYJNEGO GLEB KATIONAMI NA PLONOWANIE I SKŁAD CHEMICZNY TRAW}

Streszczenie

Przeprowadzono 3-letnie doświadczenie wazonowe $\mathrm{z}$ życica wielokwiatową na glebie słabo próchnicznej $(1,3 \%$ próchnicy) o składzie mechanicznym piasku gliniastego oraz 2-letnie doświadczenie wazonowe z kostrzewą ląkową na glinie lekkiej zawierającej 2,15\% próchnicy. Przed założeniem doświadczeń do gleb dodano zróż- 
nicowane dawki wapnia, magnezu i potasu doprowadzając je do bardzo zróżnicowanego wysycenia kompleksu sorpcyjnego kationami. Doświadczenia prowadzono w wazonach typu Wagnera zawierających $8,5 \mathrm{~kg}$ gleby. Zbierano co rok 5 odrostów życicy i 4 odrosty kostrzewy.

W miare zmniejszania pojemności sorpcyjnej gleb ich kompleks sorpcyjny powinien byc $\mathrm{w}$ większym stopniu wysycony potasem i magnezem. Wysokie plony na glebie o pojemności sorpcyjnej równej 10 m.e. otrzymano wówczas gdy było $\mathrm{w}$ nim powyżej $6 \% \mathrm{Mg}$ i $4 \% \mathrm{~K}$, natomiast na glebie o pojemności sorpcyjnej 4 m. e. na $100 \mathrm{~g}$ najwyższe plony otrzymano przy $21-27 \% \mathrm{Mg}$ i przy $10-11 \% \mathrm{~K}$ w kompleksie sorpcyjnym. Nawet duże różnice $w$ wysyceniu kompleksu sorpcyjnego wapniem nie wywarły większego wpływu na plonowanie i skład chemiczny traw. $\mathrm{W}$ miarę zwiększania dawek $\mathrm{K}$ znacznie rozszerzal się stosunek $\mathrm{K}$ : (Ca $+\mathrm{Mg}) \mathrm{W}$ trawach. Wapnowanie i nawożenie magnezem nieznacznie tylko zawężały ten stosunek. Jednakże ze względu na wysoką zawartość Ca i $\mathrm{Mg}$ w życicy i w kostrzewie nawet najwyższe dawki $K$ nie rozszerzały tego stosunku do wartości uznanej za krytyczną. Zawartość potasu w roślinie znacznie wzrastała $w$ miarę zwiększania dawek tego skladnika $\mathrm{i}$ to niezależnie od poziomu nawożenia $\mathrm{Ca}$ i $\mathrm{Mg}$. Zawartość magnezu również wzrastała w miarę zwiększania dawek $\mathbf{M g}$, ale tylko wówczas, gdy nie była ona ograniczona wysokimi dawkami K. Zawartość wapnia $\mathrm{w}$ większym stopniu uzależniona była od poziomu nawożenia potasem niż od wapnowania. 